\title{
Technology and Its Requirement for Teaching Translation and Interpreting in Disruptive Era
}

\author{
Atsani Wulansari ${ }^{1}$, Gilang Fadhilia Arvianti $^{2}$ \\ \{atsani_wulansari@untidar.ac.id1, gilangfadhilia@untidar.ac.id2\} \\ ${ }^{1,2}$ Universitas Tidar, Indonesia
}

\begin{abstract}
Technology in language learning is developing recently. Along with this, teaching translation and interpreting in university should integrate technology. Several technologies can be used in translation and interpreting, such as online dictionaries, idiom dictionaries, videos, assisted-translation tools, and so on. To integrate those technologies in translation and interpreting classroom, finding the needs is essential. Thus, this study aims to identify the need for technology in learning translation and interpreting through the perception of students, lecturers, and professional practitioners. This study applied the descriptive qualitative research method. The instruments of data collections used were questionnaire and interview. The questionnaires were distributed to students, lecturers, and professional practitioners to gain their perception of the need for technology in translation and interpreting class. The result stated that technology should be integrated in teaching translation and interpreting. The result of this need analysis is used to design the material for further translation and interpreting class.
\end{abstract}

Keywords: need analysis, technology for translation and interpreting, teaching translation and interpreting, disruptive era.

\section{INTRODUCTION}

Technology has become bread and butter for digital native students. Their life is surrounded by technological devices such as mobile phone, notebook, computer, television, etc. [1]. Their way of learning is also different. They tend to utilize their mobile phone or browse the material on the internet. In line with that, the way in teaching the digital native students should be changed to accommodate their need. Teachers could employ technological devices for their teaching-learning process to replace the traditional method. Applying computer in the classroom will help the students build their critical thinking. Moreover, the students can find the best solution to the problems [2].

Teaching translation using the traditional method which applies pencil and paper is tedious [3]. Besides, that teaching method does not fit with the characteristic of digital native students. According to Kopáčková [4], the digital native students use PC or tablets to read the material and use web-based technologies to find the information and produce the content. Therefore, the method of teaching translation and interpreting should be developed by including the technologies. One of the technologies in translation is Computer-Assisted Translation (CAT) Tools. It refers to software which helps translators complete the translation work with high efficiency and high quality. There are translation memory and terminology database in CAT 
Tools where the translators can save the terminologies and reuse them when it is needed. [5] $[6]$.

Other technologies for teaching translation and interpreting class are online dictionaries, videos, laboratories equipped with simultaneous booths and teacher console and many more. Videos can be applied in interpreting class to replace the simultaneous booth and console [7] [8]. Interpreting activity is challenging for students if they listen to a native speaker. By using the video of speech and conference from native speakers, the students not only interpret the video but also brainstorm the content of the video [8].

However, to find the best technologies and method in teaching translation and interpreting, the teachers should discover students' need. Discovering students' need is vital to find the best technologies in the classrooms that are relevant for students. Needs analysis is an important procedure both in language teaching and general or specific purposes. Need analysis is the first step in designing or developing an educational program [9]. It is necessary to recognize the students' need in the teaching and learning process. The pertinent material or technologies in translation and interpreting class will make the students engage in the teaching-learning process.

Some researchers have already done the students' need analysis research. The first study was done by Ratnaningsih \& Anggraeni [10]. It described the students' needs on Writing 3 textbook. Then, the other research was done by Wulanjani [11] in 2018. She investigated the need analysis of ESP for Civil Engineering students in a university. This research stated that the result of this research could be used for designing or developing English language material for ESP students. In relation to translation and interpreting, Károly[12] and Siregar et al. [13] did the studies about need analysis. Károly explored the students' needs regarding course content and methodology to assist teachers in selecting the material and approach in teaching translation. Moreover, Siregar et al. found the need analysis for designing translation textbook base on Teaching English as a Foreign Language (TEFL) Pedagogical purpose. The researches mentioned above have stated that student need analysis is the crucial step in designing, developing or creating an educational scheme.

According to the background of the study and also the previous research, this study intended to identify the need for technology in learning translation and interpreting through the perception of students, teachers, and professional practitioners. The result of this research expectantly gives the implication for lecturers to apply technology in translation and interpreting class.

\section{METHODOLOGY}

This research used descriptive qualitative research. The participants of this research were 76 students of Translation and Interpreting in the academic year of 2018/2019 in Universitas Tidar, five lecturers of translation or translation and interpreting from different cities in Indonesia and seven translation practitioners who work as a freelance and full-time translator in Indonesia.

In gaining the data, the researchers used an online questionnaire and interview. The surveys consisted of close question were made through Google form and delivered to the students, lecturers, and practitioners. The questionnaire for students of translation and interpreting contained ten questions about their need for learning material and activities. It used scale 1 (strongly disagree) to 4 (strongly agree). This questionnaire was adapted from Mutlu [14]. Then, the questionnaire for lecturers and practitioners contained two aspects. The first aspect was about their personal experience in teaching translation or working in 
translation industry, and the second aspect was concerning their opinion for the technology needed by students. There were two questions on the first aspect and ten questions on second aspects.

This research applied a needs-analysis model proposed by Altschuld and Witkin (1995) in [9]. This model presented four stages such as preparation, data collection, data analysis and the final report. In the preparation stages, the researchers made the questionnaire and chose the participants. Then, the data collection stage was aimed to gather the data. Therefore, spreading the survey and doing the interview were done in this stage. The coding of the data was also done.

To analyze the data, the researchers calculated data gathered from questionnaires into a percentage. Then it was presented through figures and table. After that, all the data from the questionnaire and interview were described and interpreted. The discussion of the finding was also done to get the conclusion.

\section{RESULT AND DISCUSSION}

The result of the questionnaire and interview will be presented in detail here.

\subsection{The result of the Students' Need Analysis Questionnaire}

Based on the questionnaire given to students, the response could be seen on the table below.

Table 1. The Result of Students' Need Analysis

\begin{tabular}{|c|c|c|c|c|c|}
\hline No & Aspect & 1 & 2 & 3 & 4 \\
\hline 1. & $\begin{array}{l}\text { Learning practical skills in translation and interpreting is } \\
\text { essential for the students }\end{array}$ & & & $65,8 \%$ & $34,2 \%$ \\
\hline 2. & $\begin{array}{l}\text { Students need to be more in touch with courses at a practical } \\
\text { level by using technologies }\end{array}$ & & $1,3 \%$ & $75 \%$ & $23,7 \%$ \\
\hline 3. & $\begin{array}{l}\text { Course materials have helped me in improving my skills in } \\
\text { translation and interpreting }\end{array}$ & & $3,9 \%$ & $75 \%$ & $21,1 \%$ \\
\hline 4. & $\begin{array}{l}\text { The course can prepare a student for starting a profession in } \\
\text { Translation and Interpreting }\end{array}$ & $1,3 \%$ & & $64,5 \%$ & $34,2 \%$ \\
\hline 5. & Students should be provided with more real-life projects & $1,3 \%$ & $6,6 \%$ & $76,3 \%$ & $15,8 \%$ \\
\hline 6. & $\begin{array}{l}\text { Classes need to be more collaborative between teachers and } \\
\text { students/ students and students }\end{array}$ & & & $76,3 \%$ & $23,7 \%$ \\
\hline 7. & $\begin{array}{l}\text { The course given make me more interested in Translation and } \\
\text { Interpreting }\end{array}$ & & $4,7 \%$ & $74,2 \%$ & $21,1 \%$ \\
\hline 8. & $\begin{array}{l}\text { Instructors use a variety of techniques to motivate and } \\
\text { encourage students }\end{array}$ & & $1,3 \%$ & $73,7 \%$ & $25 \%$ \\
\hline 9. & $\begin{array}{l}\text { Students are encouraged to work, practice and do projects out } \\
\text { of the class context }\end{array}$ & $1,6 \%$ & $3,7 \%$ & $77,6 \%$ & $17,1 \%$ \\
\hline & $\begin{array}{l}\text { I got familiarized with market demands and business of } \\
\text { Translation through the materials covered or my instructors }\end{array}$ & $1,4 \%$ & 18,4 & $69,7 \%$ & $10,5 \%$ \\
\hline No & $\begin{aligned} \text { e: } & \\
1 & : \text { strongly disagree } \\
2 & : \text { disagree } \\
3 & : \text { agree } \\
4 & : \text { strongly agree }\end{aligned}$ & & & & \\
\hline
\end{tabular}


The questionnaire above asked about the situation in the teaching-learning process and their needs in translation and interpreting class. From that questionnaire, it could be seen that students needed to learn practical skills in translation and interpreting by using technologies. The course given by the lecturers, previously, only introduced the students about technologies in translation and interpreting. Thus, the students needed to get more in touch with technology. However, students agreed that the course materials given had helped the students in improving their skills in translation and interpreting and can prepare them for starting a profession in Translation and Interpreting. Dealing with the market demand for translation and interpreting field, students needed with more real-life project so that they got familiarized with market demands and business of translation and Interpreting through the materials.

In the interview session, there were six questions delivered to students. The questions were about the activity, material, and technology in translation and interpreting class. From the activity in translation, it was found that most of the students wanted to practice on translating genres of the text and doing subtitling. Similar to translation activity, students wanted to practice more by doing some projects outside for interpreting activity. In addition, almost all of the students explained that they needed the technology for translation and interpreting. They said that technology could help them and developed their skill in translation and interpreting.

\subsection{Lecturers' Perspective of Technology in Translation and Interpreting}

There were two aspects of questions in questionnaire delivered to lecturers. The first aspect is about their personal experience in teaching translation and interpreting and the second aspect is concerning their opinion for the technology needed by students. The result of the questionnaire is elaborated as follows.

\subsubsection{Personal Experience in Teaching Translation and Interpreting}

\section{How long have you been teaching translation and interpreting? 5 tanggepan}

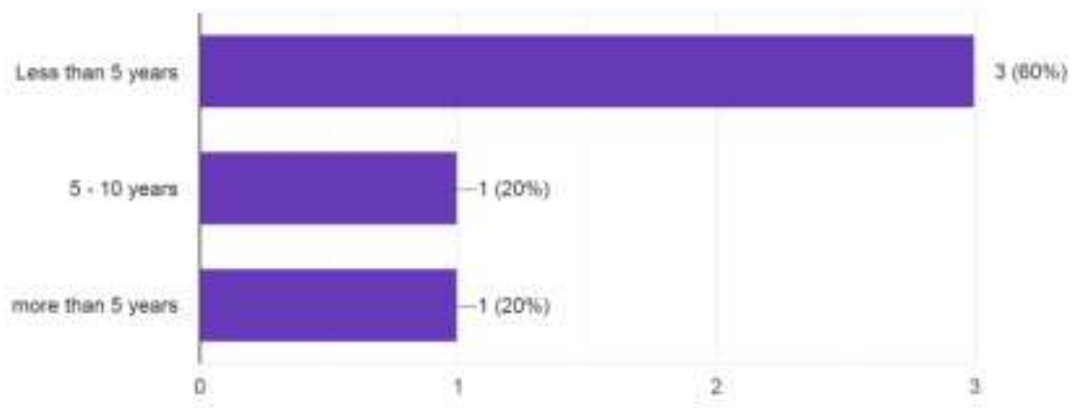

Fig 1. Duration of Teaching Translation and Interpreting

Most of the lecturer participants in this research taught translation less than five years. When they asked about the method they used in translation and interpreting class, they said that discussion, collaborative approach, peer-reviewing were used in their class. More practising and gaming were also suggested to be applied in class. All lecturers admitted that 
they applied technology in their class because it is crucial for their future. Moreover, technology is unavoidable in this disruptive era. The interview was also carried out to know more about technology the lecturers applied in translation and interpreting class. From the interview, it was summarized that in their class, the lecturers of translation and interpreting used multimedia, Aegisub for subtitling, online dictionary, Socrative, Matecat, video and YouTube. Most of the lecturers avoided using Google translate in their class and always asked the students to use the online dictionary. Then, the lecturers applied technology when there was a topic dealing with technology such as subtitling and technology in translation and interpreting. However, some of them utilized the technology most often in class. The figure below is the result of using technology in class.

\section{Do you apply technology in your translation and interpreting class?}
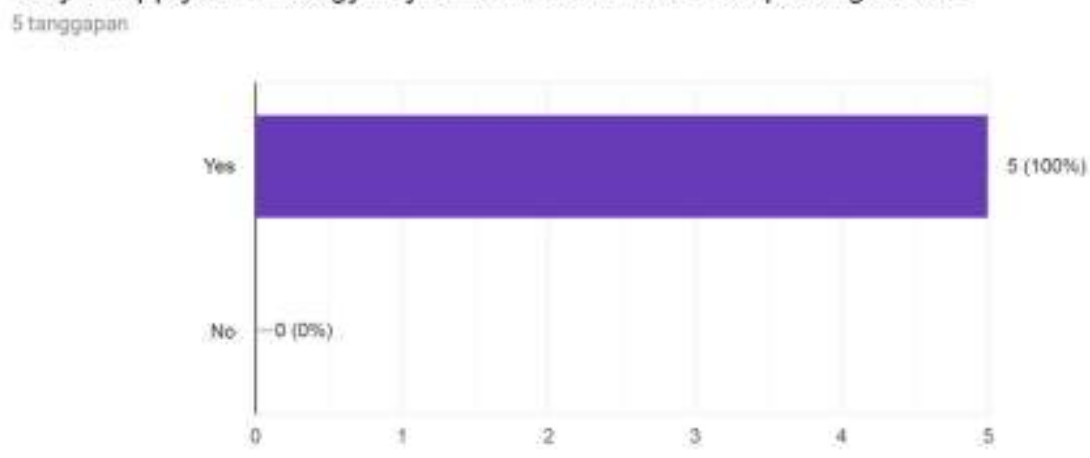

Fig 1. The Use of Technology in Teaching Translation and Interpreting

\subsubsection{The lecturers' opinion for the technology needed by students}

The questionnaire was presented to lecturers to gather their opinion about using technology in translation and interpreting class. Based on the questionnaire given to lecturers, the response could be seen on the table below.

Table 2. The Result of Lecturer's Opinion

\begin{tabular}{|c|c|c|c|c|c|}
\hline No & Aspect & 1 & 2 & 3 & 4 \\
\hline 1. & $\begin{array}{l}\text { Translation students need to learn technology such as CAT Tools } \\
\text { in Translation }\end{array}$ & & & $40 \%$ & $60 \%$ \\
\hline 2. & $\begin{array}{l}\text { By learning technology used in translation, the students can } \\
\text { compete in this era }\end{array}$ & & & $40 \%$ & $60 \%$ \\
\hline 3. & Technology helps students in translating the text & & & $60 \%$ & $40 \%$ \\
\hline 4. & $\begin{array}{l}\text { Technology not only helps students in translating activity but also } \\
\text { in interpreting activity }\end{array}$ & & & $60 \%$ & $40 \%$ \\
\hline 5. & $\begin{array}{l}\text { By applying CAT Tools, the students can improve their } \\
\text { translation skills and results }\end{array}$ & $20 \%$ & & $40 \%$ & $40 \%$ \\
\hline 6. & $\begin{array}{l}\text { Be able to use one of technology in translation is the requirement } \\
\text { in translation business }\end{array}$ & & & $40 \%$ & $60 \%$ \\
\hline 7. & $\begin{array}{l}\text { Technology in translation such as machine translation, translation } \\
\text { memory, and online dictionary should be included in translation }\end{array}$ & & & $60 \%$ & $40 \%$ \\
\hline
\end{tabular}


and interpreting curriculum

8. Technology in interpreting such as video, webcast should be $\quad 60 \% \quad 40 \%$

included in translation and interpreting curriculum

9. The teachers and students do not need to have face to face $80 \% \quad 20 \%$ meeting in class due to technology

10. It is effective to apply technology in translation and interpreting $\quad 60 \% \quad 40 \%$ class.

Note:

1. : strongly disagree

2. : disagree

3. : agree

4. : strongly agree

From the result of the questionnaire above, it was conveyed that most of the lecturers agreed that technology in translation and interpreting should be included in translation and interpreting curriculum. It was needed since technology is compulsory in this disruptive era. One of the examples is that the students who are able to use one of technology in translation will compete better in industry. Moreover, mastering one of technology in translation and interpreting is the requirements to be involved in translation and interpreting industry. The previous research done by Wulansari [6] presented this statement, as well.

Furthermore, the result of the interview revealed the technology lecturers wanted to apply in their class. Most of the lecturers mentioned that they wanted to utilize technology that can support students in improving their skill, and covering all ability in translation and interpreting. Some of the lecturers expressed that they wanted to apply Trados and free Cat tools for their teaching and learning process. They also suggested creating a website or application to support the teaching and learning process.

\subsection{Translation Practitioners' Perspective of Technology in Translation and Interpreting}

Similar to the questionnaire delivered to lecturers, there were two aspects of questions in the questionnaire for practitioners. The first aspect was about their personal experience in translation and interpreting field, and the second aspect was concerning their opinion for the technology needed by students. The result of the questionnaire is shown in the following table. 


\subsubsection{Personal Experience in Translation and Interpreting Field}

How long have you been working in translation and interpreting?

7 tanggapan

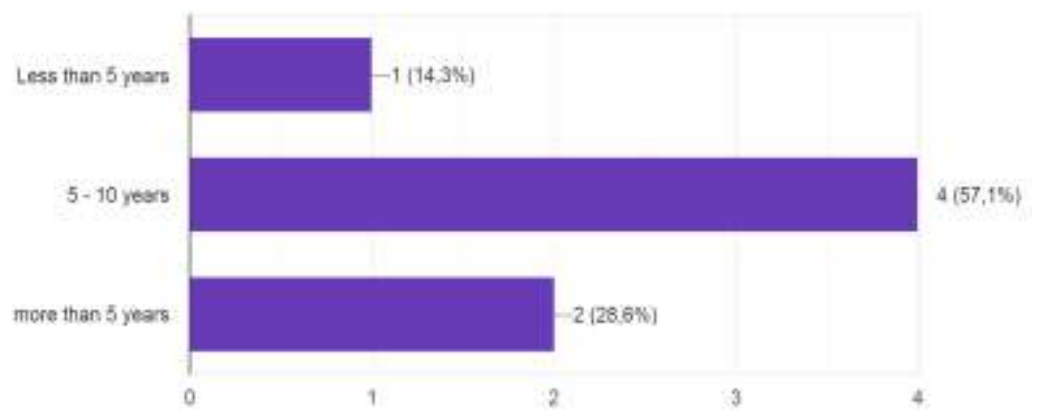

Fig 3. Duration of Working in Translation and Interpreting Field

\section{Do you apply technology in doing translation and interpreting activity?} 7 tingoganan

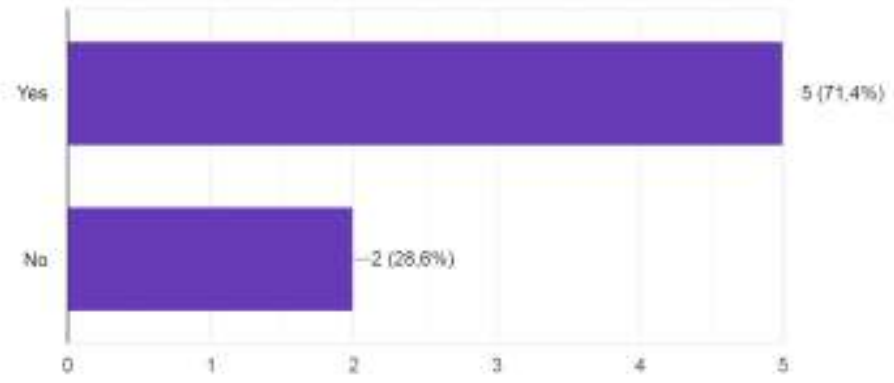

Fig 4. Applying Technology in Translation and Interpreting

From those figures, it could be concluded that the participants in this research had been working for five years, and most of them used technology in their activity. From the interview, it was revealed that they applied online dictionary, glossary, Matecat and Memo Q for translation activity. Meanwhile, for interpreting, no one used the technology like booth and console.

\section{3. 2 The Practitioners' Opinion for the Technology Needed by Students}

The questionnaire was delivered to practitioners to gather their opinion about using technology in translation and interpreting class. The response could be seen on the table below. 
Table 3. The Result of Practitioners' Opinion

\begin{tabular}{|c|c|c|c|c|}
\hline No & Aspect & 2 & 3 & 4 \\
\hline 1 . & $\begin{array}{l}\text { Translation students need to learn technology such as CAT } \\
\text { Tools in Translation }\end{array}$ & & $42,9 \%$ & $57,1 \%$ \\
\hline 2. & $\begin{array}{l}\text { By learning technology used in translation, the students } \\
\text { can compete in this era }\end{array}$ & & $57,1 \%$ & $42,9 \%$ \\
\hline 3. & Technology helps students in translating the text & & $57,1 \%$ & $42,9 \%$ \\
\hline 4. & $\begin{array}{l}\text { Technology not only helps students in translating activity } \\
\text { but also in interpreting activity }\end{array}$ & & $100 \%$ & \\
\hline 5. & $\begin{array}{l}\text { By applying CAT Tools, the students can improve their } \\
\text { translation skills and results. }\end{array}$ & & $85,7 \%$ & $14,3 \%$ \\
\hline 6. & $\begin{array}{l}\text { Be able to use one of technology in translation is the } \\
\text { requirement in translation business }\end{array}$ & & $57,1 \%$ & $42,9 \%$ \\
\hline 7. & $\begin{array}{l}\text { Technology in translation such as machine translation, } \\
\text { translation memory, and online dictionary should be } \\
\text { included in translation and interpreting curriculum }\end{array}$ & & $57,1 \%$ & $42,9 \%$ \\
\hline 8. & $\begin{array}{l}\text { Technology in interpreting such as video, webcast should } \\
\text { be included in translation and interpreting curriculum }\end{array}$ & & $57,1 \%$ & $42,9 \%$ \\
\hline 9. & $\begin{array}{l}\text { The teachers and students do not need to have face to face } \\
\text { meeting in class due to technology }\end{array}$ & $85,7 \%$ & $14,3 \%$ & \\
\hline & $\begin{array}{l}\text { It is effective to apply technology in translation and } \\
\text { interpreting class }\end{array}$ & & $42,9 \%$ & $57,1 \%$ \\
\hline $\begin{array}{r}\text { Note: } \\
1 . \\
2 . \\
3 . \\
4 .\end{array}$ & $\begin{array}{l}\text { strongly disagree } \\
\text { disagree } \\
\text { agree } \\
\text { strongly agree }\end{array}$ & & & \\
\hline
\end{tabular}

The result of the questionnaire above showed that most of the practitioners agreed that technology in translation and interpreting should be included in translation and interpreting curriculum. The result was similar to the lecturers' perception. Then, from the interview, they also suggested the technology for translation and interpreting class such as the online dictionary, thesaurus, glossary and the affordable CAT Tools. Those technologies, based on their opinion, helped the students a lot, and they were necessary for providing accurate translation work.

\section{CONCLUSION}

From the questionnaire spread to students, lecturers, and professional practitioners, it can be concluded that technologies are needed to support translation and interpreting class. Besides to improve the students' skill in practising translation and interpreting, using technologies can also prepare students with market demand and business of translation and interpreting in real life. Deal with it; lecturers also need technologies that can support students in improving their skill, and covering all ability in translation and interpreting. New website and application are needed to support class activity. Professional practitioners agreed that using technologies in translation and interpreting class must be added in the curriculum in university since the students must be prepared with demand and business of the real-life in 
translation and interpretation. The result of this research hopefully, could be used to design the material or website for further translation and interpreting class.

\section{Acknowledgement}

We would like to express our gratitude to Ministry of Research, Technology and Higher Education which supported this research. We also express our special thanks to LPPM-PMP and the students of Translation and Interpreting, Universitas Tidar, Magelang, Indonesia which helped us in doing the research and to all people who I cannot mention one by one.

\section{REFERENCES}

[1] S. T. Yong, P. Gates, and I. Harrison, "Digital Native Students- Where is the evidence?," Online J. New Horizons Educ., vol. 6, no. 1, pp. 46-58, 2016.

[2] R. G. Muir-herzig, "Technology and its impact in the classroom," Comput. Educ., vol. 42, pp. 111-131, 2004.

[3] R. Hartono, "Teaching Translation Through The Interactive Web," Lang. Circ. J. Lang. Lit., vol. IX, no. April, pp. 129-140, 2015.

[4] H. Kopáčková, "Characteristics of digital natives generation in the context of mobile learning," 2016, no. July 2015.

[5] ZHOU Wei and GAO Bei, "Study on the Application of Computer-Aided Translation (CAT) in Translation Teaching," US-China Foreign Lang., vol. 14, no. 12, pp. 849856, 2016.

[6] A. Wulansari, "CAT Tools: The Challenge for Translation Learning in 4.0 Era," English Lang. Lit. Int. Conf. Proc., vol. 2, no. 0, pp. 537-540, Jul. 2018.

[7] B. Wang, "Bridging the gap between interpreting classrooms and real-life interpreting," Int. J. Interpret. Educ., vol. 7, no. 1, pp. 65-73, 2015.

[8] C. Degueldre and C. V Angelelli, "Implementing New Technologies in the Teaching of Interpreting," Cuad. ALDEEU, no. 25, pp. 253-269, 2013.

[9] N. N. Shahri and Z. B. Farimani, "A students' Needs-analysis Study of Translation Studies Curriculum offered at Master's level in Iranian Universities," Res. English Lang. Pedagog., vol. 4, no. 1, pp. 26-40, 2016.

[10] E. Ratnaningsih and C. W. Anggraeni, “The Students' Needs of Writing 3 Textbook," Metathesis J. English Lang. Lit. Teach., vol. 01, no. 2, pp. 61-67, 2017.

[11] A. N. Wulanjani, "Exploring Students' Need for Developing Material of English for Civil Engineering," Metathesis J. English Lang. Lit. Teach., vol. 2, no. 1, p. 1, 2018.

[12] A. Károly, "Exploring learners' needs and expectations: Translating EU texts in an English bachelor's program at a Hungarian college," WoPaLP, vol. 6, pp. 58-85, 2011.

[13] M. Siregar, T. S. Sinar, A. Saragih, and S. Lubis, "Need Analysis for Developing Translation's Textbook base on TEFL Pedagogical Purpose in Indonesia: English Teachers' Perspectives," Adv. Lang. Lit. Stud., vol. 9, no. 3, p. 81, 2018.

[14] Özlem Mutlu, "A Needs Analysis Study for the English-Turkish Translation Ccourse Offered to Management Students of the Faculty of Economic and Administrative Sciences at Baskent University," Middle East Technical University, 2014. 